\title{
Youth, race and the inner-city estate: narratives of everyday life in Manchester's Hulme, 1970-1994
}

\author{
Isabelle Carter* \\ Nicola De La Haye Building, University of Lincoln, Lincoln, LN6 7TS, UK \\ ${ }^{*}$ Corresponding author. Email: icarter@lincoln.ac.uk
}

\begin{abstract}
Since the 1970s, policy-makers and the press have rendered young people, particularly those of black and minority ethnic backgrounds, synonymous with 'inner-city crisis'. Focusing upon the high-density, multi-storey Hulme estate in Manchester, this article seeks to transcend stereotypical representations of these residents and illuminate their perspectives of the inner city. Conceptualizing the inner city as both a discursive and lived space, the article traces the intersections between its representation and residents' testimonies to assess how far residents used prevalent understandings of Hulme as a space of crime and social breakdown respectively to shape their narratives of everyday life.
\end{abstract}

On 2 March 1993, a photograph in the Manchester Evening News showed a group of children gathered to witness the demolition of the Hulme Crescents. ${ }^{1}$ The image signalled a new beginning for the estate. With traditional, low-rise housing replacing high-density, multi-storey flats, the redevelopment represented a bid to strengthen Hulme's appeal to families once more. In the three decades between the estate's construction and demolition, safety concerns saw Manchester City Council attempt to remove families with young children from blocks of high flats in Hulme. ${ }^{2}$ Their absence facilitated the arrival of an increasingly transient population of young, single and black and minority ethnic tenants who, according to policy-makers and the press, began to epitomize the sense of 'inner-city crisis' apparent in particular urban spaces of late twentieth-century England. ${ }^{3}$ Cultural

\footnotetext{
1‘The crescents come crashing down', Manchester Evening News, 2 Mar. 1993.

${ }^{2}$ Manchester Archives (MA), GB127/76, Manchester City Council Housing Committee, 'A new method of administering, determining and meeting housing accommodation needs', Minute Book 76: December 1975-March 1976 (Manchester, 1976), 156.

${ }^{3}$ M. Glendinning and S. Muthesius, Tower Block: Modern Public Housing in England, Scotland, Wales and Northern Ireland (London, 1994), 326. On press coverage of Hulme, see P. Shapely, 'The press and the system-built developments of inner-city Manchester, 1960s-1980s', Manchester Region History Review, 16 (2003), 30-9. On the 'decline' of multi-storey council housing in England, see A. Ravetz, Council Housing and Culture: The History of a Social Experiment (London, 2001), 104-9; P. Hall, Cities

(c) The Author(s), 2021. Published by Cambridge University Press. This is an Open Access article, distributed under the terms of the Creative Commons Attribution licence (http://creativecommons.org/licenses/by/4.0/), which permits unrestricted re-use, distribution and reproduction, provided the original article is properly cited.
} 
and political representations emphasized 'the density, the anarchy, and the chaos' of Hulme, rendering its new, supposedly 'alternative community' synonymous with crime, drug abuse and the material deprivation of the built environment. ${ }^{4}$ For newspapers like the Manchester Evening News then, the bulldozing of multistorey Hulme and the return of families with young children in the 1990s symbolized the estate's much-needed 'inner-city rebirth'.

This presentation of Hulme's history has led to the homogenization of the inner-city estate's lived experience. By restrictively categorizing Hulme tenants according to tropes of urban deprivation, it has obscured the perspectives of those residents who did not fit with dominant representations of the estate's demographic changes over time. This article seeks to correct this imbalance. With a focus upon discourses of youth, race and inner-city decline articulated by policymakers and the press, as well as residents' personal testimonies of Hulme, the article demonstrates how individuals negotiated wider representations of everyday life in an urban space linked to the 'crisis' of the inner city. ${ }^{6}$ It argues that the lived experience of the inner city is indivisible from its discursive construction. In a recent reassessment, Michael Romyn called for the amplification of residents' voices to guard the future study of the post-war inner city against 'myth, spectacle and abstraction'. Indeed, as the Introduction to this Special Issue notes, the perspectives of the people who called the inner city home have long been side-lined in its wider representation. Yet it is precisely this representation, combined with the material realities of the inner city, that residents used to frame their accounts of everyday life, drawing on Hulme's racialization, and association with disorderly young people, to alternately refute and consolidate stereotypes of inner-city housing estates.

The article draws upon oral history interviews with 10 former residents and the testimonies of local people recorded through community projects. It connects recent research into the conceptual, political and transnational roots of the inner city, to scholarship of the lived experience of high flats and council housing

of Tomorrow: An Intellectual History of Urban Planning and Design in the Twentieth Century (Oxford, 1988), 246-7; I. Cole and R. Furbey, The Eclipse of Council Housing (London, 1994), 149.

${ }^{4}$ S. Stone, 'The Haçienda: the manufactured image of a post-industrial city', Interiors, 5 (2014), 42; O. Hatherley, A Guide to the New Ruins of Great Britain (London, 2010), 126.

${ }^{5}$ Minister sees inner-city rebirth', Manchester Evening News, 9 Jun. 1995.

${ }^{6}$ For examples of the hyperbolic nature of press coverage relating to Hulme, see 'Close-up: the concrete jungle', Daily Mirror, 28 Oct. 1977; 'Never again', Manchester Evening News, 9 Apr. 1981; 'Knock down this disgraceful estate', Observer, 5 Jan. 1986; 'No place like Hulme: housing dream that became a nightmare', Manchester Metro News, 24 Apr. 1992. On the relationship between personal narratives in oral history and cultural discourses, see P. Summerfield, Histories of the Self: Personal Narratives and Historical Practice (London, 2019), 115-18; H. Mills, 'Using the personal to critique the popular: women's memories of 1960s youth', Contemporary British History, 30 (2016), 468; L. Abrams, Oral History Theory (Abingdon, 2010), 55; A. Portelli, 'Oral history as genre', in M. Chamberlain and P. Thompson (eds.), Narrative and Genre (London, 1998), 23. On the intersection of individual narratives more broadly with discourses of post-war Britain, see E. Robinson, C. Schofield, F. Sutcliffe-Braithwaite and N. Thomlinson, 'Telling stories about post-war Britain: popular individualism and the "crisis" of the 1970s', Twentieth Century British History, 28 (2017), 268-304.

${ }^{7}$ M. Romyn, “London badlands": the inner city represented, regenerated', London Journal, 44 (2019), 150; M. Romyn, 'The Heygate: community life in an inner-city estate, 1974-2011', History Workshop Journal, 81 (2016), 197-230. 
more broadly, to trace how the mythology of the inner-city estate shapes residents' stories of their childhood, teenage and student years in Hulme. ${ }^{8}$ Intersecting and overlapping aspects of youth in post-war Britain form the backdrop to its analysis, such as the rise of the teenager in the 1960s, anxieties over juvenile delinquency and the emergence of subcultural groups, all of which were underscored by issues relating to race, class and gender. ${ }^{9}$ By highlighting the ways in which residents framed their lived experience in the context of such developments, the article adds another dimension to the study of youth in post-war British cities. Moreover, its focus upon the testimonies of those residents who moved to Hulme as children and did not leave until adulthood helps to complicate the estate's enduring association with transient young tenants. Nevertheless, some voices remain absent. There is scant archival evidence of the personal testimonies of those residents who struggled with the extremes of poverty that also characterized the material reality of the inner city, with their mobility complicating efforts to access their lived experience. The testimonies considered here therefore represent a selective view of everyday life in Hulme, but one valuable to understanding the ways in which individuals constructed their accounts against prevailing discourses of the inner city.

The article begins by outlining Hulme's political and cultural representation, showing how certain groups of residents became integral to its depiction as an inner-city estate in the late twentieth century. It then considers residents' interactions with these discourses, exploring first the contradictions and inconsistencies between and within individual testimonies relating to crime and anti-social behaviour, and differing approaches to aspects of Hulme's representation as a 'ghetto', 'concrete jungle' and 'inner-city' development. The final section examines the ways in which residents adapted ideas of social breakdown in Hulme. It demonstrates how residents used the notion of Hulme's spatial and demographic demarcation as an inner-city estate to highlight interracial bonds of community relative to both the rest of Manchester and other parts of Britain. The article concludes that,

\footnotetext{
${ }^{8}$ On the inner city, see A. Kefford, 'Disruption, destruction and the creation of "the inner cities": the impact of urban renewal on industry, 1945-1980', Urban History, 44 (2017), 492-515; A. Andrews, 'Multiple deprivation, the inner city, and the fracturing of the welfare state: Glasgow, c. 1968-78', Twentieth Century British History, 29 (2018), 605-24; S. Gunn, 'The rise and fall of British urban modernism: planning Bradford, circa 1945-1970', Journal of British Studies, 49 (2010), 849-69; O. Saumarez-Smith, 'The inner city crisis and the end of urban modernism in 1970s Britain', Twentieth Century British History, 27 (2016), 133-50. On the lived experience of high flats, see L. Abrams, L. Fleming, B. Hazley, V. Wright and A. Kearns, 'Isolated and dependent: women and children in high-rise social housing in post-war Glasgow', Women's History Review, 28 (2019), 794-813; L. Abrams, A. Kearns, B. Hazley and V. Wright, Glasgow: High-Rise Homes, Estates and Communities in the Post-War Period (Abingdon, 2020). On council housing, see M. Hollow, 'The age of affluence revisited: council estates and consumer society in Britain, 1950-1970', Journal of Consumer Culture, 16 (2016), 279-96; B. Jones, The Working-Class in Mid-Twentieth-Century England (Manchester, 2012), 120-36; M. Clapson, Working-Class Suburb: Social Change on an English Council Estate, 1930-2010 (Manchester, 2012).

${ }^{9}$ For discussions of youth in post-war Britain, see S. Kenny, 'A radical project: youth culture, leisure, and politics in 1980s Sheffield', Twentieth Century British History, 30 (2019), 557-84; M. Worley, No Future: Punk, Politics and British Youth Culture, 1976-1984 (Cambridge, 2017); L.A. Jackson and A. Bartie, Policing Youth: Britain, 1945-70 (Manchester, 2014), 145-73; B. Osgerby, Youth in Britain since 1945 (Oxford, 1998).
} 
although inseparable from wider conceptualizations, residents' testimonies suggest a more complex understanding of the inner city as a lived space than previously acknowledged.

\section{Representations of inner-city Hulme}

In February 1985, the Manchester Evening News sent local journalist Russell Jenkins to live in Hulme for three weeks to uncover the 'reality' of life on the estate. The resulting double-page article, however, headlined 'Horrors of the concrete jungle', only reinforced well-established tropes of multi-storey council housing in the inner city. Jenkins described Hulme as 'a world of tranquilizers, chronic ill-health, racial tension, casual crime, glue sniffing among the kids and dope pushers living upstairs'. ${ }^{10}$ The article rendered the very presence of young people symptomatic of the estate's deprivation, outlining how 'two-thirds of the flats are lived in by a floating population of students, college drop-outs and young single people', an influx of tenants who 'brought drug dealers eager to supply a ready market, petty thieving, mugging and vandalism in its wake'. ${ }^{11}$ The spectres of crime and anti-social behaviour overshadowed depictions of the racial and ethnic diversity of these residents. 'Hulme is a breeding ground of clashing cultures', Jenkins wrote in relation to 'the young blacks', 'the poor Irish' and 'the young whites' resident in Hulme, all of whom the journalist likened to 'extras in a picture about inner-city decay'. ${ }^{12}$

As the Evening News article demonstrates, wider representations of Hulme rarely acknowledged the structural components of its deprivation. Conflating ethnic diversity and the presence of young people with social breakdown and rising crime levels, cultural discourses of the estate cultivated an image of an archetypal group of inner-city residents. The frequency of such depictions and their exaggerated nature created a powerful story of the inevitability of inner-city decline, simplifying and standardizing the lived experience of the Hulme's wider tenant population. This, in turn, helped to justify the demolition of its multi-storey blocks in the early 1990s, spaces by then associated with almost inherent poverty. Manchester City Council's approach to managing

\footnotetext{
${ }^{10}$ 'Horrors of the concrete jungle', Manchester Evening News, 22 Feb. 1985.

${ }^{11}$ On mugging and its representation in the media, see S. Hall, C. Critcher, T. Jefferson, J. Clarke and B. Roberts, Policing the Crisis: Mugging, the State and Law and Order (London, 1978), 72-7. Manchester City Council recorded 'violence against the person', a category of crime that encompassed a range of offences from common assault to grievous bodily harm and murder, as one of the most commonly recorded types of crime committed in Hulme alongside sexual assaults and robberies. Residents cited a specific 'fear of being mugged' in consultations with Manchester City Council. However, assault and robberies were the most common recorded incidents in Hulme. However, some local people considered the police presence that accompanied reports of criminal activity 'insensitive' and 'heavy-handed', with this mistrust leading to a drop in levels of reported crimes in the mid-1980s. Consequently, the police expected its rates to be much higher than recorded. See Ahmed Iqbal Ullah Race Relations Resource Centre (RRRC), GB3228.3/7/3, Manchester City Council, Deck Access Disaster: Report of the Hulme Conference Held at Birley High School, Manchester on 22nd February, 1985 (Manchester, 1985), 51; Manchester City Council Planning Department, Hulme Baseline Study: A Portrait of Hulme before Hulme City Challenge (Manchester, 1993), 75; RRRC/GB3228.3/7/33, Central Manchester Health Authority, Department of Public Health, Health and Hulme 1992: Report of Hulme Rapid Appraisal Project (Manchester, 1993), 19.

${ }^{12}$ 'Horrors', Manchester Evening News, 22 Feb. 1985.
} 
the flats seemed only to bolster this narrative. By the mid-1980s, families with young children had mostly left Hulme's largest multi-storey blocks after changes to the council's housing allocation and transfer schemes. ${ }^{13}$ The amendments, sparked by resident outrage over children's safety in the flats following the death of a five-year-old boy after falling from his fifth-floor balcony in 1975, saw the council offer housing to young, single tenants and the city's growing student population to avoid leaving flats empty. ${ }^{14}$

Students played a key role in developing Hulme's subsequent reputation for activism and left-wing radicalism. In 1982, the 17 new student members of Hulme's Constituency Labour Party participated in calls for a boycott of the local Labour club for failing to challenge the discrimination of lesbian and gay members, in addition to a vote of no confidence in its leadership. This led local political figures like MP Gerald Kaufman to condemn the rise of what he dubbed the "'bedsitter brigade"'. ${ }^{15}$ Despite party political tensions, there is little indication that conflict was more widespread across the estate, with oral history testimonies and those recorded for the Hulme Views Project suggesting that the student and remaining established tenant population in Hulme co-existed largely without incident. A study by Manchester City Council in the late 1980s estimated that one in five of all Hulme residents were students, most of whom had little interaction with local people and left soon after graduating. ${ }^{16}$

By 1986, Hulme had the highest rate of youth unemployment in Manchester, with members of the West Indian community feeling its effects most acutely. ${ }^{17}$ A non-profit organization called the Hulme People's Rights Centre, formed in the late 1970s to provide practical support to tenants in housing, social and financial need, described the estate as 'the worst example of modern inner-city deprivation and urban redevelopment. Heavily multi-racial... with a high unemployment rate, especially amongst the young. ${ }^{18}$ It characterized Hulme as a 'transit camp' where, rather than establish community bonds, residents instead looked for 'release'. ${ }^{19}$ According to these local studies, the paradoxical transience and involuntary permanence of unemployed young people, students and black and minority ethnic residents caused a population imbalance that contributed to the breakdown of community on the estate.

\footnotetext{
${ }^{13}$ MA/GB127/76, Manchester City Council Housing Committee, 'Housing accommodation needs', 156.

${ }^{14}$ MA/GB127/77, Manchester City Council director of housing, 'Deck access estates', Minute Book 77: 12 April 1976-14 June 1976 (Manchester, 1976), 853. On resident reactions to the boy's death, which included a protest march and a petition to the council to rehouse children away from the Crescents, see MA/GB127/ 76, Manchester City Council Housing Committee, 'Hulme V rehousing campaign: report of the director of housing', Minute Book 76: December 1975-March 1976 (Manchester, 1976), 135-9.

${ }^{15}$ S. Fielding and D. Tanner, 'The "rise of the left" revisited: Labour party culture in post-war Manchester and Salford', Labour History Review, 71 (2006), 221.

${ }^{16}$ RRRC/GB3228.3/4/1, Manchester City Council Hulme Project, Who Lives in Hulme? A Report on Hulme's Population Based on Census Information (Manchester, 1987), 3.

${ }^{17}$ RRRC/GB3228.3/2/5, Capita, University of Glasgow, The Wilkinson Hindle Halsall Lloyd Partnership, Cobham Resource Consultants, The Hulme Study: Volume 1 (1989).

${ }^{18}$ MA/Q362.104209HU1, Hulme People's Rights Centre, Inner City Crisis: Manchester's Hulme (Manchester, 1977), 3.

${ }^{19}$ Ibid., 12.
} 
The Manchester and Salford Inner City Partnership reached similar conclusions in 1978 when they noted, 'the problem area of most concern is that of young people in the inner city'. ${ }^{20}$ It found that youths of 'immigrant groups' especially experienced a 'disenchantment' with their environment that often led them 'into trouble'. ${ }^{21}$ Focusing in particular upon deck-access estates like Hulme and the 'considerable hostility' provoked among residents towards their design, the Partnership legitimized claims publicized by the press that sheltered walkways, once considered ideal for socializing with neighbours and allowing children to play free from vehicular traffic, had transformed into an ideal space for muggings, where crime could be committed unchecked. ${ }^{22}$ Such reports drew heavily upon the work of city planner and architect Oscar Newman and the geographer Alice Coleman, with several articles explicitly citing their research. In 1973, Newman articulated his theory of 'defensible space', through which he identified a causal relationship between crime rates and the design of high-rise housing in New York. ${ }^{23}$ His conclusions informed Coleman's approach to the study of highdensity, multi-storey estates in London in the mid-1980s, which she described as environments that engendered, 'stress, trauma...crime, fear, anxiety, marital breakdown and physical and mental disorders' among residents. ${ }^{24}$ As Daniel Warner shows in the context of football stadiums in Liverpool, the discursive construction of 'delinquent' groups could combine with this correlation between poor design and urban disorder to spark changes to material spaces across the inner city. ${ }^{25}$ Once the visual embodiment of Britain's welfare project, it seemed that mass, multi-storey estates like Hulme had transformed into archetypal symbols of inner-city deprivation.

Public organizations and the press thus saw socio-economic indicators of innercity deprivation as co-existent with the actions of certain residents who, delineated by age, race and ethnicity, worsened its effects. Press coverage in the early 1990s showed how little representations of youth, crime and anti-social behaviour in Manchester's inner city had changed in the years since the Inner City Partnership report. In January 1993, members of a local gang fatally shot a 14-year-old boy named Benji Stanley in Moss Side, an area neighbouring Hulme that the press often viewed as interchangeable with the estate. The news reached national papers, which linked Benji's death to the 'gang rule' seemingly inherent

\footnotetext{
${ }^{20} \mathrm{MA} / 309.262 \mathrm{Ma} 2$, Manchester and Salford Inner City Partnership, Inner City Manchester: Preliminary Report on Problems, Priorities and Key Issues (Manchester, 1978), 8. On the formation and rationale of 'Partnership authorities', see P. Shapely, Deprivation, State Interventions and Urban Communities in Britain, 1968-79 (London, 2017), 8.

${ }^{21}$ Manchester and Salford Inner City Partnership, Inner City Manchester, 8.

${ }^{22}$ 'Deck-access' refers to Hulme's architectural design, in which walkways linked multi-storey blocks above the ground. 'Skyscraper blocks more vulnerable to crime', Times, 26 Oct. 1972; 'The built-in crime wave of tower blocks', Times, 11 Feb. 1974; 'High-rise estate "in crisis", Guardian, 21 Sep. 1977; 'Council housing: a post-war tragedy', Times, 29 Aug. 1978; 'Knock down this disgraceful estate', Observer, 5 Jan. 1986; 'The people's revolt against modernism', Observer, 13 Jan. 1986; 'Estates crime cut by removing walkways', Times, 17 Jan. 1986.

${ }^{23}$ O. Newman, Defensible Space: Crime Prevention through Urban Design (New York, 1973), 4.

${ }^{24}$ A. Coleman, Utopia on Trial: Vision and Reality in Planned Housing (London, 1990), 3.

${ }^{25}$ D. Warner, 'When Saturday comes: football, public disorder and Liverpool's urban crisis, c. 19651985', in this issue of Urban History.
} 
to inner-city areas populated by young people. ${ }^{26}$ The Daily Mail made another connection, using an image of the Hulme Crescents to accompany its coverage, despite Hulme's geographical separation from the killing. ${ }^{27}$ For the newspaper, Hulme's inculpability in this instance mattered little. As the article explained, 'Moss Side is a generic name for all that is rundown and bad in Manchester. It takes in about a single square mile and is divided into two parts: Hulme and Moss Side proper. It is Hulme, an area of slum devastation, that has given rise to the "Bronx of Britain" tag. ${ }^{28}$

The Mail's implication of Hulme in coverage of Benji's death shows how stereotypes of the 'inner-city estate' became attached to certain locations. In the late twentieth century, a narrow selection of housing developments in Britain, like the Red Road flats in Glasgow and Sheffield's Park Hill, as well as inner-city areas of the US, like the New York City borough of the Bronx, bore the brunt of wider political and cultural representations of urban spaces. ${ }^{29}$ Using the US 'experience', the press foreshadowed the rising deprivation and criminality apparently endemic to places like Hulme. $^{30}$ The Mail underscored its transatlantic framing of the inner city with racialized tropes of violence and conflict, asking, '[i]s the death of Benji Stanley a sign that Britain is set on a course of ghetto violence to match the worst excesses of America?'31 It was not alone in its portrayal of the Manchester estates. The Daily Express, the Manchester Evening News and the Guardian all featured reports of 'Britain's Bronx', the 'Bronx of Britain', and 'Bronx's killer streets' in relation to Hulme and Moss Side in the early 1990s. ${ }^{32}$ By erasing both regional and national disparities between estates, and focusing upon the demographic characteristics of particular groups of residents, the press discursively constructed a homogeneous 'inner city' capable of extrapolation onto different urban areas.

Images of the inner city also had a part to play in its representation. The photographs accompanying coverage of Benji's death in the Mail and newspapers like The Observer, The Times and the Daily Express showed groups of young people walking together along night-time streets, and gathered in the darkness of walkways in Hulme and Moss Side. ${ }^{33}$ In using images of shadowed or silhouetted figures to illustrate news of crime and disorder, the newspapers implicitly encouraged readers to make connections between race, the built environment and emotions such as fear.

\footnotetext{
${ }^{266}$ A Moss Side story', Observer Magazine, 21 Feb. 1993; 'Gung gangs rule the rat-runs of Moss Side', Times, 29 Jun. 1993; 'War fear on new Bronx's killer streets', Daily Express, 1 Jul. 1993.

${ }^{27}$ 'Moss Side story', Daily Mail, 9 Jan. 1993.

${ }^{28}$ Ibid.

${ }^{29}$ On the selective stigmatization of housing estates in the media, see A. Kearns, O. Kearns and L. Lawson, 'Notorious places: image, reputation, stigma. The role of newspapers in area reputations for social housing estates', Housing Studies, 28 (2013), 579-98.

${ }^{30}$ On links between racialized depictions of violence in American and British cities, see Andrews, 'Multiple deprivation', 608; Romyn, “London badlands"', 137; R. Waters, 'Black Power on the telly: America, television, and race in 1960s and 1970s Britain', Journal of British Studies, 54 (2015), 967-70.

${ }^{31}$ 'Moss Side story', Daily Mail, 9 Jan. 1993.

${ }^{32 ،}$ Gloom crescents facing hammer', Manchester Evening News, 4 Jul. 1990; 'Hulme requiem', Weekend Guardian, 23 May 1992; 'Britain's Bronx', Daily Express, 4 Jan. 1993; 'Bronx's killer streets', Daily Express, 1 Jul. 1993.

${ }^{33}$ 'Moss Side', Observer Magazine, 21 Feb. 1993; 'Gung gangs', Times, 29 Jun. 1993; 'Bronx's killer streets', Daily Express, 1 Jul. 1993.
} 
Whether photographs depicted black or minority ethnic residents or not, there remained an inherent connection between danger and figures captured in darkness illustrative of the racialization of the landscape of the inner city during this period. ${ }^{34}$ That references to Hulme as a 'ghetto', 'slum' or 'concrete jungle' accompanied these images - labels often followed by some description of the race and ethnicity of an area's local population - only seemed to consolidate this form of representation. ${ }^{35}$ These wider representations of the inner city had the power to shape narratives of the estate's lived experience, as the testimonies of the young, single and diverse residents who moved to Hulme following its post-war redevelopment demonstrate.

\section{“"It is a ghetto, but then ghettos run themselves"': tenants' negotiation of Hulme's reputation}

In the late 1970s, when he was around 10 years old, Jason moved from his family home in Moss Side to a multi-storey flat in Hulme. Contrary to popular depictions of transient young tenants, Jason, a white British man, lived in Hulme until 1989, leaving the estate in his early twenties to pursue opportunities for employment elsewhere in Manchester. ${ }^{36}$ During an oral history interview, Jason focused upon his childhood and teenage years to position his narrative in opposition to Hulme's external representation, highlighting its suitability for children, the neighbourliness of people from diverse backgrounds and the harmlessness of its young population to counter aspects of the area's stigmatization. His nostalgic retelling negated changes to Hulme's physical and social landscape during the post-war period, evoking an abstract and almost timeless sense of working-class community that endured despite the intensification of the estate's stigmatization. From making general comments about Hulme's 'brilliant' and 'fantastic' community, Jason also sought to address specific elements of Hulme's reputation, making statements like: '[t]here was never any burglaries... Nobody from Hulme was a burglar. ${ }^{37}$

Offered without prompting, Jason's consistent defence of Hulme tenants indicated the extent to which discourses of the inner city that connected the estate's young residents to crime and anti-social behaviour shaped his story. A more explicit example of this narrative positioning became apparent later in his interview, when Jason recalled conversations he had overheard about the estate on the local bus. As he recounted,

You used to get on the 263 [bus] and you'd be coming home from town, and you'd hear the people from Sale and Altrincham and people outside there going, '[Hulme is] full of junkies. It's full of drugs and prostitutes.' And you

\footnotetext{
${ }^{34}$ For discussion, see E. Hostetter, 'The emotions of racialization: examining the intersection of emotion, race, and landscape through public housing in the United States', GeoJournal, 75 (2010), 283-93.

${ }^{35}$ For national examples, see 'The relief of Liverpool', Times, 11 Aug. 1972; 'Nightmare life in the concrete jungle', Times, 7 Oct. 1972; 'Warning of “urban crisis” in Britain', Times, 21 May 1973; 'The Moss Side mob', Guardian, 15 Dec. 1990. For a discussion of the visual representation of youth, race and violence in a local context, see S. Hirsch and D. Swanson, 'Photojournalism and the Moss Side riots of 1981: narrowly selective transparency', History Workshop Journal, 89 (2020), 221-45; K. Connell, Black Handsworth: race in 1980s Britain (Oakland, 2019), 53-90.

${ }^{36}$ Jason interview with author, 3 Mar. 2020.

${ }^{37}$ Ibid.
} 
were sat there thinking, 'have they ever got off the bus? Have they ever walked through it? Or have they just heard all the bullshit stories that somebody else heard from somebody else, heard from somebody else?' But as I got older, I started challenging them, especially when I was 15 or 16 . I used to say, 'I live here. I don't do drugs. I don't even smoke weed. Never been in trouble with the law. Weird that, isn't it? ${ }^{38}$

Here, Jason's testimony illuminates the other side of the 'moving up' narrative explored by Rob Waters in 'Respectability and race between the suburb and the city'. Jason used the journey between the city and the suburbs - a trajectory entwined with the respectability politics that led people to move from the inner city to its outskirts - to directly confront stigmatizing attitudes towards Hulme. ${ }^{39}$ Jason's conviction of the invalidity of Hulme's judgement is especially noteworthy considering the contradictory testimony of Conor, another long-term tenant. A white Irishman whose family relocated to England from Dublin, Conor also moved to the estate as a child in the mid-1970s, but he offered a different perspective of Hulme's young people and their involvement with criminal activity during his interview. As Conor remembered,

[There were] a lot of burglaries. We got burgled a couple of times. People would break in to steal the meter [money]. They were so easy to break in [to], we could even do it ourselves...As a young kid, I remember doing it myself, when I walked up to the house, knocking on the door and putting my hand through the letterbox and you could open the door. They were so easy to break into. ${ }^{40}$

Conor's narrative adhered more closely to Hulme's dominant reputation. While he was the victim of burglary during his tenancy, he conceded that he also broke into people's homes as a teenager, undermining Jason's assertion that '[n] obody from Hulme was a burglar. ${ }^{41}$ Conor and Jason spoke about the same time and place in their interviews. The contrasts between their accounts demonstrate the extent to which residents framed their experiences differently depending upon how they chose to relate their individual stories of the inner city to its wider discursive construction. For Jason, this intersection provided an opportunity to confront damaging representations of Hulme's young tenants. For Conor, it involved reinforcing tropes of inner-city life.

James Greenhalgh has contended that understanding the lived experience of housing estates is essential to moving beyond dichotomous portrayals of residents as 'unwitting, powerless victims', or 'the sole architects of their own demise'. ${ }^{42}$ Recognizing the extent to which tenants' stories about the nature of everyday life

\footnotetext{
${ }^{38}$ Ibid.

${ }^{39} \mathrm{R}$. Waters, 'Respectability and race between the suburb and the city: an argument about the making of "inner-city" London', in this issue of Urban History.

${ }^{40}$ Conor interview with author, 28 Feb. 2020.

${ }^{41}$ Jason interview.

${ }^{42}$ J. Greenhalgh, Reconstructing Modernity: Space, Power and Governance in Mid-Twentieth Century British Cities (Manchester, 2017), 158.
} 
in the inner city are complex and sometimes contradictory is a vital component of the same process of understanding. In constructing their accounts, residents told stories that both diverged from, and incorporated aspects of, Hulme's dominant representation as a crime-ridden inner-city estate. Complicating attempts to differentiate between the lived and discursive spaces of the post-war inner city, residents' adaptations not only led to inconsistencies between retellings, but within individual accounts too. Towards the end of his interview, Jason told stories about how he and his friends used to 'smoke weed' together, and how he often came into conflict with the police due to his association with a local 'gang' the 'Hulme Boys'. This contrasted with his earlier statements, 'I don't even smoke weed' and '[I have] never been in trouble with the law. ${ }^{43}$ In attempting to counter Hulme's reputation for crime and anti-social behaviour on behalf of the wider tenant population, Jason had initially dismissed the contradictory aspects of his own testimony. Yet due to, rather than despite, their inconsistencies, accounts like his are vital to understanding interviewees as individuals whose complex personal histories intersect with the reputation of the post-war inner city. ${ }^{44}$

While oral history interviews demonstrate how residents articulated their lived experience retrospectively, community publications illuminate the varied ways in which Hulme tenants negotiated stigmatizing discourses of the inner city in the late twentieth century. Tenant and student Kevin described to the Hulme Views Project, a group created by tenants on the eve of the estate's demolition in partnership with the Joseph Rowntree Foundation, how he 'hit the ghetto' by moving to Hulme. ${ }^{45}$ A black British man, Kevin had struggled to find shared accommodation with "so-called liberated students" elsewhere in Manchester due to the colour of his skin, but in Hulme he found a place where 'people from all kinds of backgrounds...feel accepted'. ${ }^{46}$ In his description of the estate, Kevin used the term 'ghetto' to denote his affiliation to Hulme - a 'ghetto' in which residents 'accepted' one another without prejudice - adapting the language typically ascribed to innercity council housing by the press to produce a counter narrative of his lived experience. ${ }^{47}$ Fellow resident Eve did something similar when she wrote, '[i]t is a ghetto, but then ghettos run themselves. People work together here - well, sometimes and learn from each other...there's a definite, genuine community spirit. ${ }^{, 48}$

\footnotetext{
${ }^{43}$ Jason interview.

${ }^{44}$ On interpretive approaches to inconsistencies and 'truth' in oral history, see A. Portelli, 'The peculiarities of oral history', History Workshop, 12 (1981), 99; S. Polishuk, 'Secrets, lies and misremembering: the perils of oral history interviewing', Frontiers: A Journal of Women Studies, 19 (1998), 14; Summerfield, Histories of the Self, 111-15.

${ }^{45}$ MA/GB127.M781, Hulme Views Project, Hulme Views, Self Portraits: Writing and Photographs by Hulme People (Manchester, 1990). For discussion of a similar project in the 1980s, see K. Connell, 'Photographing Handsworth: photography, meaning and identity in a British inner city', Patterns of Prejudice, 46 (2012), 136-42.

${ }^{46}$ MA/GB127.M857/1/15, Hulme Views Project, Views from the Crescents: Writing Photographs and Illustrations by People from the Crescents Area of Hulme (Manchester, 1991).

${ }^{47}$ On residents' adaptation of stigmatizing labels, see T. Slater and N. Anderson, 'The reputational ghetto: territorial stigmatisation in St Paul's, Bristol', Transactions of the Institute of British Geographers, 37 (2011), 540.

${ }^{48}$ Hulme Views Project, Views from the Crescents. Unlike Kevin's, Eve's testimony makes no mention of her ethnicity.
} 
The testimonies of these residents transformed the meaning of the 'ghetto', reworking its association with reports of violence and crime to indicate instead an inclusive community space.

However, residents' interpretations of labels associated with Hulme rarely aligned. In her interview, Jenny candidly conceded Hulme's association with the 'concrete jungle', using the term to describe the estate in the first words she spoke. For Jenny, a white woman, the connotations of the phrase, so often deployed to explain high instances of crime, did not detract from her sense of identification with and belonging to Hulme. She even outlined how her sons refer to the area as the 'Bronx', engaging with wider representations of the post-war estate that have transcended its present-day circumstances. ${ }^{49}$ For Marline though, a black woman, terms like 'concrete jungle' had a different meaning altogether. In her contribution to the Hulme Views Project, she wrote, 'About [the mid-1970s] outside influences started calling it the "Concrete Jungle" because it was assumed that (and maybe rightly so) a lot of black people were living on the Crescents. Black people were from jungles, so what better place to put them back. ${ }^{50}$ Unlike Jenny, Marline's reference to Hulme as a 'concrete jungle' was implicitly bound to the racialization of the inner city, rendering the term inseparable from its use to depict Hulme as a place of lawlessness and disorder.

Residents' approaches to Hulme's association with the 'inner city' revealed similar tensions. For Louise, a middle-class white woman who spent her student years in Hulme, moving to the estate represented an 'exciting' opportunity to live 'somewhere proper inner city'; a place that was 'a little bit scary' and 'a whole world away' from the 'straitlaced' life she had led previously in the rural village in Worcestershire where she grew up. ${ }^{51}$ Hulme represented a chance for a more liberated way of life for tenants like Louise, one at odds with those of longer-term residents who invoked Hulme's association with the inner city to demonstrate its resilience in the face of chronic underinvestment and multiple deprivation, affirming that 'the living heart of the inner city still beats, however faintly' ${ }^{52}$ Jason's view of the inner city also contained contradictions. As he stated, 'I'm just, well, inner city, but not, like. I hate the city.' Yet Jason recognized how Hulme's ties to the inner city also enabled him to construct a narrative of mobility, in economic, social and geographic terms. Not only did his work with the Hulme Sports Programme derive from inner-city funding, but it also led to other opportunities that enabled him to move away from the estate and start an adult life independent of his parents. ${ }^{53}$

In some respects, these residents embodied stereotypical representations of Hulme tenants. Jason and Conor had both engaged in anti-social behaviour even crime - to some extent during their teenage years, with Conor eventually spending time in prison. Kevin, Eve and Louise, all students, lived in Hulme only temporarily, occupying the Crescent flats once intended for families with

\footnotetext{
${ }^{49}$ Jenny interview with author, 24 Feb. 2020.

${ }^{50}$ Hulme Views Project, Views from the Crescents.

${ }^{51}$ Louise interview with author, 25 Feb. 2020.

${ }^{52}$ Hulme Views Project, Views from the Crescents.

${ }^{53}$ Jason interview.
} 
young children. Jenny and Marline were both members of single-parent families, a group typically used to exemplify 'social stress' in Hulme. ${ }^{54}$ However, residents' testimonies provide contextual information key to counteracting one-dimensional political and cultural representations of youth and race in the inner city, offering a view of the estate from the perspectives of long- and short-term tenants. Narratives of everyday life, whether articulated during an oral history interview or through a community project, represented an opportunity for these residents to rework what it meant to live in an inner-city estate.

\section{'We lived in a kind of bubble': reclaiming narratives of inner-city estates}

In 1983 at the age of 13, Stephanie, a black woman of Jamaican heritage, visited a seaside town in Wales for a school trip. By this time, aside from a short-lived family relocation to Nigeria when she was three years old, Stephanie had hardly left Manchester. Arriving in Wales with her classmates as a teenager, Stephanie soon realized that her reception from local people differed to the one she received at home. So stark was this contrast that, up to the present day, the visit stands out in Stephanie's memory as 'my first experience of racism. ${ }^{55}$ Alison went on the same school trip and made a similar point to Stephanie. As a white British woman, Alison did not experience racism herself, but she witnessed its infliction upon her peers as a teenager on several occasions in places outside of Hulme. 'It was just racism', she described, 'people...were racist towards our friends. ${ }^{56}$

In both Alison's and Stephanie's narratives, the story of the school trip and subsequent visits to Wales worked to emphasize the comparative diversity and racial tolerance of the community in Hulme. As Stephanie explained,

There's no community like it, or there was no community like it. I mean, it was so diverse. Everyone says, or everyone seems to think, it was a really black area - it wasn't. It was so diverse back then. We just didn't experience [racism]...it was just really diverse and quite ahead of the times like that really. I think we lived in a kind of bubble. ${ }^{57}$

For Stephanie, Hulme's apparent insulation from the racism experienced elsewhere set the estate apart. ${ }^{58}$ The high concentration of black and minority ethnic groups resident in Hulme, who were considered factors in its multiple deprivation by the local authority, instead helped foster an environment free from overt discrimination. While nostalgia permeated these accounts, connecting individuals to Hulme irrespective of its material or demographic changes over time, they demonstrate how residents adapted understandings of Hulme's spatial and cultural

\footnotetext{
${ }^{54}$ Capita et al., The Hulme Study: Volume 1.

${ }^{55}$ Stephanie interview with author, 4 Mar. 2020.

${ }^{56}$ Alison interview with author, 11 Mar. 2020.

${ }^{57}$ Stephanie interview.

${ }^{58}$ For discussion of 'anti-racism' in British race relations, see K. Hammond-Perry, London is the Place for Me: Black Britons, Citizenship and the Politics of Race (Oxford, 2016), 90-125; C. Schofield and B. Jones, "'Whatever community is, this is not it": Notting Hill and the reconstruction of 'race' in Britain after 1958', Journal of British Studies, 58 (2019), 170-3.
} 
distinctiveness relative to the wider city and other parts of post-war Britain. ${ }^{59}$ While the estate's association with the inner city ensured its categorization with similar 'pockets' of urban deprivation across post-war Britain, it also marked the area as separate from the rest of Manchester. Hulme tenants embraced this, transforming its division into an asset rather than a failing.

According to Lee-Ann, Hulme's demographic distinctiveness relative to other parts of Manchester led to an informal network of support among tenants. Lee-Ann, who had lived in Hulme since her birth in 1970, described how she felt accepted in Hulme regardless of her ethnicity. With grandparents from Nigeria, Ireland and England, Lee-Ann came from a diverse family, but, contrary to press reports of Hulme's 'clashing cultures', this was not a source of conflict. ${ }^{60}$ As Lee-Ann stated in her interview,

[People] got on because there wasn't a lot, people were just striving to live... When my Gran married my Grandad, she got disowned because she married a black man, but where we lived [in Hulme], every other house was a black family, so we all just got on and it wasn't obvious. I never remember people saying the 'n-word'... where we lived, but you heard it in other areas. It wasn't like that [in Hulme], everybody was friends, you were friends with other people, and I think that's because everybody was in the same boat. ${ }^{61}$

Lee-Ann's testimony points to a sense of almost colour-blindness in Hulme, whereby any differences between residents based on race and ethnicity were not 'that obvious', and through which deprivation operated as a unifying feature. ${ }^{62}$ Like the accounts preceding this, racial slurs were something expected in other areas', but not in Hulme. By emphasizing how 'everybody was friends' regardless of their race or ethnicity, Lee-Ann used her narrative to address aspects of Hulme's discursive construction as a site of social breakdown. She stressed instead the endurance of the estate's community, evoking a side of the inner city rarely featured in its wider representation.

The testimony of Shaima, a woman of Pakistani heritage, offered another perspective. Shaima had lived with her family on the estate from 1969, when she was just one year old, until she reached 31 in 1999. During her interview, she recalled largely positive memories of Hulme, although her experience of community differed from those of other respondents. Shaima asserted at several points during her interview that Hulme had a 'community feel', the presence of which had encouraged her family to remain in the area rather than looking for a house elsewhere. Nevertheless, she acknowledged that 'there were a few issues, you know, racism, things like that'. 'I'd get picked on', Shaima recounted, 'on the way

\footnotetext{
${ }^{59}$ On nostalgia and place, see K. Bennet, 'Telling tales: nostalgia, collective identity and an ex-mining village', in M. Smith, J. Davidson, L. Cameron and L. Bondi (eds.), Emotion, Place and Culture (Farnham, 2009), 189.

${ }^{60}$ Manchester Evening News, 22 Feb. 1985.

${ }^{61}$ Lee-Ann interview with author, 24 Nov. 2019.

${ }^{62}$ On narratives of 'colour-blindness', see C. Weedon, Identity and Culture: Narratives of Difference and Belonging (Maidenhead, 2004), 63.
} 
home from school, or stopped. But I'd have my siblings who would help me out. ${ }^{, 63}$

This was Shaima's first acknowledgement of racism in her interview and she initially sought to downplay its role in her memories of Hulme. However, as the conversation continued, she began to offer more details.

There was one boy on the estate, he had lots of brothers, I think he had one sister...he was a bit of a - he wasn't that nice, he used to call me names... [she recalls a confrontation between him and her older sister], [her sister] was like 'well, where are your ancestors from?!' She went absolutely mad because she was very high on politics and stuff like that...he never did [anything like that again]. Then there was one girl, she was nasty, she weren't racist, she just stopped me, she just picked on me for something...The majority of kids in the class were West Indian or white. In my class there was only me and one boy who were Asian. There weren't that many, because there weren't that many on the estate where we were. ${ }^{64}$

While Shaima brushed off the association of parts of these confrontations with racism, her narrative connection between these experiences - the first of which she explicitly identified as racist - and the minor presence of Asian residents like herself relative to other ethnic groups when growing up, suggests that racial tensions did define aspects of Shaima's time in Hulme. Moreover, despite the far-reaching networks of sociability alluded to in Lee-Ann's interview, this did not prove representative of Shaima's experience. In Hulme, people of Nigerian and Jamaican heritage represented the largest ethnic minority group, leading to the development of numerous Afro-Caribbean social and cultural organizations for residents that likely facilitated the growth of the support networks of which Lee-Ann spoke. Indeed, a 1987 study of the local population by Manchester City Council reported that Hulme's 'historical role as an immigrant area' and the difficulties that people experienced when trying to be rehoused from the estate had given rise to a more tolerant community than found in other parts of the city. ${ }^{65}$

Hulme's Asian population was small relative to the rest of Manchester and tended to be concentrated in areas closer to Moss Side. According to census data of the late 1970s, the Pakistani population represented a minor but well-established group in the city, as did people of Indian, Bangladeshi and West Indian heritage. ${ }^{66}$ Of these groups, the 1987 study reported that Asian communities 'have been known to have their own network of social contacts' in Hulme. Somewhat reinforcing this, although Shaima described her family as having 'lots of friends' among their neighbours, she recalled how her mother was particularly keen to befriend other Asian women. One of their family's closest friends remained a woman who Shaima's mother once saw on the estate dressed in traditional clothes, which Shaima remarked was a rarity at the time (the 1970s) in Hulme. This connection

\footnotetext{
${ }^{63}$ Shaima interview with author, 26 Feb. 2020.

${ }^{64}$ Ibid.

${ }^{65}$ Manchester City Council, Who Lives in Hulme?, pp. 6-7.

${ }^{66} \mathrm{MA} / \mathrm{Q} 312.094273 \mathrm{MA}(918)$, Manchester City Planning Department, Manchester's Population and Housing: The Results of the Local Authority Census, 1978 and the National Dwelling and Housing Survey, 1978 (Manchester, 1981), p. 18.
} 
subsequently led to their introduction to other Asian families, with the parents and children respectively forming friendships based initially on their shared heritage, and its absence among other local families. ${ }^{67}$

The contrasts between Lee-Ann's and Shaima's experiences demonstrate the myriad ways in which immigration shaped different parts of the inner city over time, highlighting the importance of local case-studies in determining the lived experiences of places so often subjected to homogeneous representations. Shaima's testimony also shows both how former residents attempted to revise Hulme's poor reputation, and the ways in which this could come into conflict with their other, less positive, memories of the estate. Even when she recounted racist incidents of her childhood and teenage years, Shaima sought to minimize their role to conclusively characterize Hulme in terms of its unified 'community feel'. In this sense, Shaima's portrayal of Hulme ultimately aligned with the accounts of other residents, through which the indicators of inner-city deprivation used to differentiate the area from other urban spaces, like its disproportionate number of young, black and minority ethnic tenants and high levels of socioeconomic deprivation, were addressed and reassessed. A similar identification of the racial inclusivity of certain spaces of the inner city emerged among the oral history participants of Sue Zeleny Bishop's study of intercultural romances in Leicester. As Bishop notes, the inner city acted as a space of 'possibilities' for its residents and visitors alike, facilitating social and cultural opportunities distinct from other parts of the city. ${ }^{68}$ Offering an alternative view of Hulme's lived experience, these narratives cultivated connections between residents based on the sense of community and racial tolerance particular to its inner-city setting.

\section{Conclusion}

Manchester's Hulme seemed to epitomize a growing sense of 'inner-city crisis' in post-war England. Focusing upon its high-density, multi-storey blocks and their occupation by young and black and minority ethnic groups of residents, policymakers and the press discursively constructed Hulme as a space of crime, disorder and social breakdown. Aspects of its history, such as Manchester City Council's efforts to rehouse families with young children away from high flats, the estate's increasing use as student accommodation and the fact of its demolition and redevelopment, only reinforced its dominant representation in the late twentieth century. Observers connected the built environment to the actions of certain inhabitants, drawing parallels between urban areas across Britain and the US to lend a sense of inevitability to Hulme's experience of multiple deprivation. Political and cultural discourses thus rationalized structural issues evident across Manchester's inner city as the fault of a deviant minority, leaving little room for alternative perspectives.

This article has used residents' personal testimonies to redress this balance. It has shown that, despite their limitations, representations of the inner city were

\footnotetext{
${ }^{67}$ Shaima interview.

${ }^{68}$ S.Z. Bishop, 'Inner-city possibilities: using place and space to facilitate inter-ethnic dating and romance in 1960s-1980s Leicester', in this issue of Urban History.
} 
tied to its lived experience. In their accounts of everyday life, residents used political and cultural discourses of Hulme as an inner-city estate to shape stories that challenged and consolidated the meaning of the inner city as both a discursive and lived space. While some accepted popular depictions of Hulme, others sought to defend the estate's wider population from stigmatization. Moreover, tenants used the notion of Hulme's distinctiveness as a primarily 'inner city', rather than solely urban space, to cast its separation from other areas of Manchester and parts of postwar Britain more broadly in a positive light, reconfiguring damaging connotations of inner-city living to emphasize instead the strengths of Hulme's community. Throughout, the article draws upon the accounts of longer-term residents who lived in Hulme during their childhood and teenage years, as well as the students more often connected to depictions of the estate's transience. In so doing, it highlights the voices of tenants typically absent from representations of the inner city. While these accounts help to complicate one-dimensional depictions of Hulme by emphasizing experiences of continuity alongside change, further research is needed to capture the perspectives of the estate's most vulnerable residents.

For the Hulme tenants considered here, the inner city was home; a place influential to their day-to-day lives, and one that remained so beyond the period of 'crisis' typically ascribed to urban areas of the late twentieth century. Yet, the cultural and political connotations of the inner city did translate into residents' lived experiences, especially for those groups at the heart of its vilification. This did not mean that tenants accepted aspects of Hulme's representation without question. Instead, they selectively interacted with wider discourses to tell stories that offered more positive accounts of everyday life in the inner city, as well as those that acknowledged its limitations. Their perspectives demonstrate the ongoing nature of reclaiming narratives of the post-war inner city. Eschewing a simplistic dichotomy of good and bad, these individuals reworked the meaning of the inner city on their own terms, shedding light on the multifaceted nature of this particular urban space.

Cite this article: Carter I (2023). Youth, race and the inner-city estate: narratives of everyday life in Manchester's Hulme, 1970-1994. Urban History 50, 248-263. https://doi.org/10.1017/S0963926821000754 